\title{
Genetics of pulmonary arterial hypertension: do the molecular findings have translational value? Nicholas W Morrell
}

\author{
Address: Department of Medicine, Box 157, Addenbrooke's Hospital, University of Cambridge School of Clinical Medicine, Hills Road, \\ Cambridge, CB2 8DP, UK \\ Email: nwm23@cam.ac.uk
}

fl000 Biology Reports 2010, 2:22 (doi:10.3410/B2-22)

The electronic version of this article is the complete one and can be found at: http://fl000.com/reports/biology/content/2/22

\begin{abstract}
Pulmonary arterial hypertension (PAH) is usually a devastating condition with a poor prognosis. Nearly 10 years ago, the underlying molecular basis of heritable $\mathrm{PAH}$ was elucidated with the identification of mutations in the gene encoding the bone morphogenetic protein type II receptor (BMPR-II). This discovery is now beginning to suggest novel approaches to therapy in heritable PAH. Moreover, recent studies provide evidence that dysfunction of the BMPR-Il pathway is a feature of non-familial forms of PAH, broadening the scope for intervention in this pathway.
\end{abstract}

\section{Introduction and context}

Idiopathic and familial forms of pulmonary arterial hypertension (PAH) continue to carry a poor prognosis despite significant improvements in the treatment of these and related conditions over the past 15 years. Existing therapies are based on the replacement of prostanoids, inhibition of the endothelin pathway, or enhancement of nitric oxide signaling. Although these therapies have improved symptoms and possibly survival of some patients, additional approaches founded on a more thorough understanding of the cell and molecular pathobiology of PAH are required. Nearly 10 years ago, heterozygous germline mutations in the gene encoding bone morphogenetic protein type II receptor (BMPR-II), on chromosome $2 q 33$, were identified in families affected by PAH $[1,2]$. To date, mutations in BMPR-II have been identified in nearly $80 \%$ of affected families. In addition, $10-40 \%$ of apparently sporadic cases of idiopathic PAH have been found to harbour mutations in BMPR-II [3]. Mutations have been identified in almost all of the coding exons of the BMPR2 gene. Approximately 30\% of mutations are missense, causing substitution of highly conserved amino acids in important functional domains of the receptor (e.g., the ligand-binding or kinase domains) [3]. The remaining (approximately 70\%) comprise nonsense, frameshift, and splice-site defects, and gene rearrangements. These predict premature termination of the transcript with likely loss through the process of nonsense-mediated decay (NMD). Disease penetrance in mutation carriers varies between families but is usually less than $50 \%$. This important observation suggests that, although heterozygous mutation in BMPR-II increases the risk for PAH more than $10^{5}$-fold, some additional environmental or genetic factor seems to be a requirement for disease manifestation [4]. Evidence for genotype-phenotype correlations is slowly emerging in that missense mutations have been associated with earlier age of onset and increased penetrance compared with other mutations [5]. In addition, certain low-penetrance alleles seem more likely to occur in idiopathic PAH or disease associated with other known triggers $[3,6]$.

BMPR-II is a type II receptor member of the transforming growth factor-beta (TGF- $\beta$ ) superfamily. As with other TGF- $\beta$ family members, BMPs signal via complexes comprising heterodimers of type I and type II receptors [7]. The type II receptor is a constitutively active serinethreonine kinase, which in the presence of ligand phosphorylates the type I receptor. The type I receptor then phosphorylates a family of proteins termed Smads, 
which can bind to DNA either directly to alter gene transcription or in the presence of DNA-binding partners. BMPs typically activate Smads 1, 5, and 8, whereas the TGF- $\beta$ receptors typically activate Smads 2 and 3. Smad 4 is a common partner Smad that lacks a DNA-binding domain but is necessary for entry of the receptor-activated Smads to the nucleus.

In lung tissue from patients with heritable PAH, BMPR-II protein expression and phospho-Smad 1 expression are reduced $[8,9]$. Of note, expression of these key parts of the BMP signaling pathway is also reduced in $\mathrm{PAH}$ patients who have no identifiable mutation in BMPR-II [8]. In pulmonary artery smooth muscle cells (PASMCs) isolated from patients with BMPR-II mutations, phospho-Smad1/5 activation in response to BMPs is suppressed, as is the activation of key BMP target genes, including the inhibitors of differentiation (Id) genes [10]. The BMP/BMPR-II/Smad1/Id gene axis appears to be growth-suppressive in PASMCs and pro-apoptotic $[9,11]$. Overexpression of mutant BMPR-II in vascular smooth muscle cells of transgenic mice appears sufficient to induce the development of pulmonary hypertension in these animals [12], whereas heterozygous BMPR2-null mice have no clear phenotype $[13,14]$. These findings likely indicate the need for a critical reduction in the BMPR-II activity below a threshold for the manifestation of disease. It is possible that additional triggers necessary for disease manifestation may further disrupt expression of key components of this pathway or indeed BMPR-II itself. Immunohistochemistry and in vitro studies suggest that BMPR-II is most highly expressed on the vascular endothelium. In contrast to PASMCs, BMPs via BMPR-II/ Smad1/5 and Id1 are thought to enhance proliferation and reduce apoptosis of endothelial cells [15]. Conditional knockout of endothelial BMPR-II is sufficient to cause pulmonary hypertension in a proportion of mice [16].

\section{Major recent advances}

In terms of the translational value of the molecular findings, two major questions arise. First, can the restoration of BMPR-II function or expression prevent, or preferably reverse, the development of pulmonary hypertension? Second, what are the consequences to the cell of reduced BMPR-II expression or function and can these be targeted? We now know that reduced BMPR-II expression is a key feature of the two most commonly used rat models of PAH: chronic hypoxia $[17,18]$ and exposure to the plant alkaloid, monocrotaline $[17,19]$. Prevention of the reduction of BMPR-II expression by adenovirally transduced lung endothelial targeting of BMPR-II ameliorates the development of pulmonary hypertension in chronically hypoxic rats [20]. The same targeted approach is successful in the monocrotaline model, although transduction via the airways failed to have an effect [21]. There are additional approaches that might be used to restore BMPR-II function. For example, many of the mutations result in NMD of the transcript. Agents that improve translational read-through of the transcript would therefore be useful for mutations in which the resulting protein would retain some function [22]. Many of the missense mutations occur in the ligand-binding domain of BMPR-II and involve the substitution of important cysteine residues that provide tertiary structure to the molecule. These cysteine-substituted mutants fail to traffic normally to the cell surface and are held up within the endoplasmic reticulum. Though mutated, these receptors retain kinase activity, can associate with type I receptors, and retain some ligandbinding capacity. It is possible to use chemical chaperones to enhance mutant BMPR-II trafficking to the cell surface and restore BMP signaling [23]. This approach may be useful in this particular form of mutation. In addition, it is possible that the endoplasmic reticulum stress response may be activated in the presence of these mutations, which could also be a target for intervention.

One example of a pathway that is altered as a consequence of reduced BMP signaling is the TGF- $\beta$ pathway via the TGF- $\beta$ type 1 receptor, activin receptorlike kinase 5 (ALK-5). Several studies have now confirmed that ALK-5 inhibition can prevent or reverse established pulmonary hypertension in rodent models $[17,24,25]$. Another consequence of reduced BMPR-II function appears to be the increased expression of proinflammatory cytokines and inflammation [26]. These findings are still emerging but again provide additional targets for intervention.

\section{Future directions}

Further advances are required to develop a robust mouse model of BMPR-II mutation that consistently leads to pulmonary hypertension and vascular remodeling. This will depend on the identification of a trigger or second hit that precipitates disease. The unique conditions faced by the lung circulation and the localization of disease to that vascular bed are likely clues to solving this enigma. Such models will allow the testing in vivo of novel therapies designed to target BMPR-II or the BMP signaling pathway. A further challenge is to more fully understand the consequences to the vascular cell of BMPR-II mutation. Evidence is emerging that non-canonical signaling or additional hitherto unknown functions of BMPR-II may provide further insight into pathobiology and ultimately therapy. 


\section{Abbreviations}

ALK-5, activin receptor-like kinase 5; BMP, bone morphogenetic protein; BMPR-II, bone morphogenetic protein type II receptor; Id, inhibitors of differentiation; NMD, nonsense-mediated decay; $\mathrm{PAH}$, pulmonary arterial hypertension; PASMC, pulmonary artery smooth muscle cell; TGF- $\beta$, transforming growth factor-beta.

\section{Competing interests}

The author declares that he has no competing interests.

\section{References}

I. Deng Z, Morse JH, Slager SL, Cuervo N, Moore KJ, Venetos G, Kalachikov S, Cayanis E, Fischer SG, Barst RJ, Hodge SE, Knowles JA: Familial primary pulmonary hypertension (Gene PPHI) is caused by mutations in the bone morphogenetic protein receptor-II gene. Am J Hum Genet 2000, 67:737-44.

2. International PPH Consortium, Lane KB, Machado RD, Pauciulo MW, Thomson JR, Phillips JA 3rd, Loyd JE, Nichols WC, Trembath RC: Heterozygous germline mutations in BMPR2, encoding a TGF-beta receptor, cause familial primary pulmonary hypertension. Nat Genetics 2000, 26:8I-4.

3. Machado RD, Aldred MA, James V, Harrison RE, Patel B, Schwalbe EC, Gruenig E, Janssen B, Koehler R, Seeger W, Eickelberg O, Olschewski H, Elliott CG, Glissmeyer E, Carlquist J, Kim M, Torbicki A, Fijalkowska A, Szewczyk G, Parma J, Abramowicz MJ, Galie N, Morisaki H, Kyotani S, Nakanishi N, Morisaki T, Humbert M, Simonneau G, Sitbon O, Soubrier F, et al.: Mutations of the TGFbeta type II receptor BMPR2 in pulmonary arterial hypertension. Hum Mutat 2006, 27:121-32.

4. Hamid R, Cogan JD, Hedges LK, Austin E, Phillips JA 3rd, Newman JH, Loyd JE: Penetrance of pulmonary arterial hypertension is modulated by the expression of normal BMPR2 allele. Hum Mutat 2009, 30:649-54.

5. Austin ED, Phillips JA, Cogan JD, Hamid R, Yu C, Stanton KC, Phillips CA, Wheeler LA, Robbins IM, Newman JH, Loyd JE: Truncating and missense BMPR2 mutations differentially affect the severity of heritable pulmonary arterial hypertension. Respir Res 2009, 10:87.

6. Humbert M, Deng Z, Simonneau G, Barst RJ, Sitbon O, Wolf M, Cuervo N, Moore KJ, Hodge SE, Knowles JA, Morse JH: BMPR2 germline mutations in pulmonary hypertension associated with fenfluramine derivatives. Eur Respir J 2002, 20:5I8-23.

7. Miyazono K, Maeda S, Imamura T: BMP receptor signaling: transcriptional targets, regulation of signals, and signaling cross-talk. Cytokine Growth Factor Rev 2005, 16:25I-63.

8. Atkinson C, Stewart S, Upton PD, Machado R, Thomson JR, Trembath RC, Morrell NW: Primary pulmonary hypertension is associated with reduced pulmonary vascular expression of BMPR-II. Circulation 2002, I05:1672-8.

9. Yang $X$, Long L, Southwood M, Rudarakanchana N, Upton PD, Jeffery TK, Atkinson C, Chen $H$, Trembath RC, Morrell NW: Dysfunctional Smad signaling contributes to abnormal smooth muscle cell proliferation in familial pulmonary arterial hypertension. Circ Res 2005, 96:1053-63.

10. Yang J, Davies RJ, Southwood M, Long L, Yang X, Sobolewski A, Upton PD, Trembath RC, Morrell NW: Mutations in bone morphogenetic protein type II receptor cause dysregulation of Id gene expression in pulmonary artery smooth muscle cells: implications for familial pulmonary arterial hypertension. Circ Res 2008, 102:1212-21.

II. Fantozzi I, Platoshyn O, Wong $\mathrm{AH}$, Zhang S, Remillard $\mathrm{CV}$, Furtado MR, Petrauskene OV, Yuan JX: Bone morphogenetic protein-2 upregulates expression and function of voltagegated $\mathrm{K}+$ channels in human pulmonary artery smooth muscle cells. Am J Physiol Lung Cell Mol Physiol 2006, 29 I:L993-I004.
12. West J, Fagan K, Steudel W, Fouty B, Lane K, Harral J, Hoedt-Miller M, Tada Y, Ozimek J, Tuder R, Rodman DM: Pulmonary hypertension in transgenic mice expressing a dominant-negative BMPRII gene in smooth muscle. Circ Res 2004, 94: I 109-14.

13. Song $Y$, Jones JE, Beppu $H$, Keaney JF Jr, Loscalzo J, Zhang $Y Y$ : Increased susceptibility to pulmonary hypertension in heterozygous BMPR2-mutant mice. Circulation 2005, I I 2:553-62.

14. Long L, MacLean MR, Jeffery TK, Morecroft I, Yang X, Rudarakanchana N, Southwood M, James V, Trembath RC, Morrell NW: Serotonin increases susceptibility to pulmonary hypertension in BMPR2-deficient mice. Circ Res 2006, 98:818-27.

fl000 Factor 6.0 Must Read

Evaluated by Jason Yuan 06 Jun 2007

15. Valdimarsdottir G, Goumans MJ, Rosendahl A, Brugman M, Itoh S, Lebrin F, Sideras P, ten Dijke P: Stimulation of Id I expression by bone morphogenetic proetin is sufficient and necessary for bone morphogenetic protein-induced activation of endothelial cells. Circulation 2002, 106:2263-70.

16. Hong KH, Lee YJ, Lee E, Park SO, Han C, Beppu H, Li E, Raizada MK, Bloch KD, Oh SP: Genetic ablation of the BMPR2 gene in pulmonary endothelium is sufficient to predispose to pulmonary arterial hypertension. Circulation 2008, I I 8:722-30.

17. Long L, Crosby A, Yang X, Southwood M, Upton PD, Kim DK, Morrell NW: Altered bone morphogenetic protein and transforming growth factor-beta signaling in rat models of pulmonary hypertension: potential for activin receptor-like kinase-5 inhibition in prevention and progression of disease. Circulation 2009, I 19:566-76.

18. Takahashi H, Goto N, Kojima Y, Tsuda Y, Morio Y, Muramatsu M, Fukuchi $Y$ : Downregulation of type II bone morphogenetic protein receptor in hypoxic pulmonary hypertension. Am J Physiol Lung Cell Mol Physiol 2006, 290:L450-8.

19. Morty RE, Nejman B, Kwapiszewska G, Hecker M, Zakrzewicz A, Kouri FM, Peters DM, Dumitrascu R, Seeger W, Knaus $P$, Schermuly RT, Eickelberg O: Dysregulated bone morphogenetic protein signaling in monocrotaline-induced pulmonary arterial hypertension. Arterioscler Thromb Vasc Biol 2007, 27:1072-8.

20. Reynolds AM, Xia W, Holmes MD, Hodge SJ, Danilov S, Curiel DT, Morrell NW, Reynolds PN: Bone morphogenetic protein type 2 receptor gene therapy attenuates hypoxic pulmonary hypertension. Am J Physiol Lung Cell Mol Physiol 2007, 292:LI I82-L92.

21. McMurtry MS, Moudgil R, Hashimoto K, BonnetS, Michelakis ED, Archer SL: Overexpression of human bone morphogenetic protein receptor 2 does not ameliorate monocrotaline pulmonary arterial hypertension. Am J Physiol Lung Cell Mol Physiol 2007, 292:L872-8.

22. Nasim MT, Ghouri A, Patel B, James V, Rudarakanchana N, Morrell NW, Trembath RC: Stoichiometric imbalance in the receptor complex contributes to dysfunctional BMPR-II mediated signalling in pulmonary arterial hypertension. Hum Mol Genet 2008, 17:1683-94.

23. Sobolewski A, Rudarakanchana N, Upton PD, Yang J, Crilley TK, Trembath RC, Morrell NW: Failure of bone morphogenetic protein receptor trafficking in pulmonary arterial hypertension: potential for rescue. Hum Mol Genet 2008, 17:3 I80-90.

24. Zaiman AL, Podowski M, Medicherla S, Gordy K, Xu F, Zhen L, Shimoda LA, Neptune E, Higgins L, Murphy A, Chakravarty S, Protter A, Sehgal PB, Champion HC, Tuder RM: Role of the TGF-beta/Alk5 signaling pathway in monocrotaline-induced pulmonary hypertension. Am J Respir Crit Care Med 2008, 177:896-905.

25. Thomas M, Docx C, Holmes AM, Beach S, Duggan N, England K, Leblanc C, Lebret C, Schindler F, Raza F, Walker C, Crosby A, Davies RJ, Morrell NW, Budd DC: Activin-like kinase 5 (ALK5) mediates abnormal proliferation of vascular smooth muscle cells from patients with familial pulmonary arterial hypertension and is involved in the progression of experimental pulmonary arterial hypertension induced by monocrotaline. Am J Pathol 2009, 174:380-9.

26. Hagen M, Fagan K, Steudel W, Carr M, Lane K, Rodman DM, West J: Interaction of interleukin-6 and the BMP pathway in pulmonary smooth muscle. Am J Physiol Lung Cell Mol Physiol 2007, 292:LI 473-L9. 